\title{
A Study of the 4th Grade Students in Primary School through the Compositions of Their Opinions about the Classroom Environment They Want to be In
}

\author{
Muhammet Fatih Doğan*, Zeynep Doğan \\ Department of Primary Education, Yıldız Technical University, Istanbul, Turkey
}

Copyright $(2018$ by authors, all rights reserved. Authors agree that this article remains permanently open access under the terms of the Creative Commons Attribution License 4.0 International License

\begin{abstract}
The purpose of this study was to reveal the thoughts of the students who were studying at 4th grade in a primary school related to the classroom environment in their dreams. In the study, it was envisaged that the opinions of the students about the physical and emotional environments in the classroom give an idea about the desire and expectations of the students to create a more appropriate classroom environment. 114 students who were studying at 4 th grade in public school in Istanbul were involved in the study. The compositions of the students about what kind of classroom environment they want constituted the data of the study. With the data analysis, the items related to the classroom environment that students desire were organized under two main headings: Physical expectations and Emotional expectations. According to the findings, it was seen that a single study table, a private locker, an interactive smartboard, colorful furniture and design, fancy bulletin boards, a tidy environment and a clean environment were the general physical expectations of the students from the classroom environment whereas positive social relations with friends, positive communication with the teacher and the sense of success were the general emotional expectations of the students. In addition, it was observed that the students expressed a variety of opinions on technological possibilities, emergency measures, security and discipline.
\end{abstract}

Keywords Primary School Students, Classroom Environment, Composition

\section{Introduction}

The school building that is allocated for use by the students and other staff who are educated in the school, and the physical space that encloses all the educational, administrative and service units of the school is called the school building [1]. The school building is one of the main factors in order to provide the necessary benefit from the educational activities. School buildings have an important impact on the physical environment, the effectiveness of the learning-teaching process, and the development of student attitudes and behaviors [2]. In school buildings, educational environments should be established in line with the needs and expectations of the users and physical, educational and social environment arrangements should be developed to meet these needs [3]. In the primary school buildings which constitute the first stage of primary education, each class has a classroom and all the courses are taught in this place. Therefore, many educational activities are carried out in this place depending on the content of the course. In order to carry out the activities related to the content of the courses in accordance with educational philosophy and educational program, the physical space should have the equipment required by these activities and appropriate spatial organization [4]. In classrooms, the physical space should be organized to motivate students and teachers, to serve the content of the course, and to support the educational activities to be successful. According to Loughlin and Suina [5], the organization of the classroom environment is a tool that supports the learning process and the classroom design involves much more than the tables, chairs and cabinets in traditional thinking. Education environments are dynamic structures composed of sub-elements such as staff, physical space, equipment, learning tools and special arrangements. The meaning of the physical environment, which is a dimension of this structure, is the characteristics of the space reserved for educational activities. It is very important that the physical environment/conditions are consistent with the purpose and content of the program and that its features are organized in a way that will cooperate with all the elements that affect learning [6-8]. According to educators, learning can occur in an environment that is appropriate 
physically, socially and psychologically. Education environment should be organized in accordance with learning-teaching activities for effective education. This is a proof that the various dimensions of interaction between the educational environment and the individual should be organized and directed towards the educational objectives. With the recent research, educators, architects, and researchers have shown that the design of classrooms is largely effective on the behavior of children, the learning performance of children and the achievement of children $[4,9,10]$. Teachers have stated that permanent learning can be created in an environment which is appropriate in terms of physical, social and psychological aspects, comfortable and appealing to a lot of sense organs [11]. The child who is educated in a physical environment that is organized for educational purposes perceive the environment better in which it is located through various channels of influence and the level of motivation increases [12]. It is possible to create appropriate educational environments to provide the necessary effect in learning and change of behavior in the person [13]. In this sense, it is necessary to create motivating educational environments in which the student can use his / her physical and mental abilities in the best way in order to increase the level of success and maximize his / her abilities [14]. When the researches related to primary school buildings, classrooms and other educational settings are examined, it is seen that these studies are mostly carried out by professionals such as educators, psychologists, sociologists and architects. However, studies on the expectations of primary school students who are the most important element of the educational process and who get service in these educational environments have not been found much. Therefore, it is appeared to be important to study the physical structure of the classrooms of the primary school students in which they continue their education lives and all the dimensions afterwards. Thus, the aim of the study is to reveal the thoughts related to the classroom environment in the dreams of students who are studying at the 4th grade in primary school.

\section{Method}

\subsection{Research Design}

In the study, the aim was to reveal the classroom environment that 4th grade students imagined; therefore, research design was determined as case study. According to Yildirim \& Simsek [15], case study is a research method that allows a researcher to examine a phenomena or phenomenon in depth that cannot be controlled based on how and why. It is used especially when the boundaries between case and context are not fully clear.

\subsection{Research Sample}

The research was carried out with 121 students who were studying at 4 th grade in a public school in Istanbul. In the data analysis process, the data of the 7 students were excluded from the study because their writings were unreadable and some of them had irrelevant contents. Finally, the writings of 114 students were analyzed. Therefore, there were 114 students in the sample of the research.

Table 1. Sample of Research

\begin{tabular}{|c|c|}
\hline Grade level of student & 4th \\
\hline The number of students & 114 \\
\hline
\end{tabular}

\subsection{Data Collection and the Analysis of Data}

Forms prepared by the researcher were used as data collection tool and they were given to the students to write their compositions. The students were asked to write a composition about the classroom environment in their dreams. Forty minutes were given to the students. At the end of the period, the forms were collected and properly preserved.

Content analysis method was used to analyze collected data. The compositions created by the students were examined in detail and all the expressions of the students were transferred to the MS Word. Then, similar answers were put together under the same expression. The answers were examined in detail and similar answers were appropriately coded. With these encodings, main headings about the answers were formed and the answers were arranged under the appropriate headings.

\section{Findings}

According to the data obtained from the research, when the statements of the students about the classroom environment in their dreams were examined, these expressions were decided to divide into two main categories: Physical and Emotional. Table 2 contains information about the main and the sub-categories.

Table 2. Main and sub-categories of findings

\begin{tabular}{|c|c|}
\hline $\begin{array}{c}\text { Physical Expectations of the } \\
\text { Students }\end{array}$ & $\begin{array}{c}\text { Emotional Expectations of the } \\
\text { Students }\end{array}$ \\
\hline $\begin{array}{c}\text { Functional Structure of The } \\
\text { Class }\end{array}$ & Social relations \\
\hline Belongings (chair, desk, locker) & Teacher \\
\hline Chalkboard- Smartboard & Academic \\
\hline Aesthetics of The Class & Security \\
\hline & Cleaning \\
\hline
\end{tabular}




\subsection{Findings about Physical Expectations of Students}

Table 3. Expectations about student seating areas

\begin{tabular}{|c|c|c|}
\hline Expectations & f & \% \\
\hline Personal desk & 27 & 33 \\
\hline The physical features of the desk & 22 & 27 \\
\hline Tablecloth & 11 & 14 \\
\hline Softness of the desk & 5 & 6 \\
\hline Larger desks & 3 & 4 \\
\hline Other & 13 & 16 \\
\hline Total & 81 & 100 \\
\hline
\end{tabular}

When the expectations about the student seating areas were examined, it was seen that the students expected personal desks significantly. It was even understood that they cared about the physical characteristics of their desks. It was seen that different colors (white, pink, yellow, colorless), fragrant, new, clean, regular, non-porous and durable were the words that students used to define their desks. Again, colorful, regular, heart, different and clean were the words students used to define their expectations of the tablecloth. Some students stated that they wanted a soft desk with sponge. Some of the students stated that the seats should be broader rather than being singular, since 3 people sit on the same desk. Additionally, desks made from metal, a place to put pencils and water bottles on the desk, the desk for 2 students, different special desks for boys and girls were the other answers given by the students.

Table 4. Expectations about lockers

\begin{tabular}{|c|c|c|}
\hline Expectations & f & \% \\
\hline Personal Locker & 29 & 41 \\
\hline A Place to hang coats and bags & 21 & 30 \\
\hline Locker & 8 & 11 \\
\hline Teacher's locker must be locked & 5 & 8 \\
\hline Other & 7 & 10 \\
\hline Total & 70 & 100 \\
\hline
\end{tabular}

Table 5. Expectations about Board - Smartboard

\begin{tabular}{|c|c|c|}
\hline Expectations & f & \% \\
\hline The Smartboards must be bigger & 14 & 38 \\
\hline $\begin{array}{c}\text { Use SMART Board instead of normal } \\
\text { board }\end{array}$ & 5 & 14 \\
\hline Password on smart boards & 6 & 16 \\
\hline Use chalkboards & 4 & 10 \\
\hline Other & 8 & 22 \\
\hline Total & 37 & 100 \\
\hline
\end{tabular}

In the expectations about the lockers, the students stated that they wanted their own cupboard. They also needed cupboards or hangers to hang their bags and coats. However, they wanted their own closets and teacher closets to be locked. The color of the cabinets, more cabinets in the classroom, larger locker for the teacher, having a test book inside the cabinets, candy and chocolate in the cupboards is the other expectations of the students.

Table 5 shows the results of the expectations related to the Board - SMART Board.

When the expectations related to the Board and SMART Board were analyzed, it was seen that the majority of the students who expressed their opinions had the expectations that SMART Boards must be bigger and the number of them must be increased, and that they must be used instead of normal board. It was determined that some students expressed that the usage of smart boards in the classroom must be more careful. For this reason, there were also students who wanted the smartboard to have a password. In contrast, some students stated that they would like to use normal boards with chalk. Besides, the other expectations; the Board is in a place where everyone can see it, the SMART Board perceives what is said, the SMART Board is used regularly, the SMART Board is new, there should be a television instead of the SMART Board, the SMART Board should contain beautiful films and cartoons, were mentioned by the students.

When the expectations about technology were investigated, it was found that the students had academic expectations from the technology, using advanced technology, watching 3D video, using tablet instead of books and notebooks, having internet on tablets, and the smart board giving the lecture when the teacher is busy and in other areas include self-cleaning toilets and automatic seats in classrooms were the expectations of the students.

Table 6. Expectations about the aesthetic design of the class

\begin{tabular}{|c|c|c|}
\hline Expectations & f & \% \\
\hline Walls & 24 & 27 \\
\hline Windows & 17 & 19 \\
\hline Curtains & 16 & 18 \\
\hline Being colorful and fancy & 18 & 20 \\
\hline Painting the floor & 5 & 5 \\
\hline Other & 10 & 11 \\
\hline Total & 90 & 100 \\
\hline
\end{tabular}

Under this subtitle, thoughts about the walls, windows and curtains were voiced. Most intensely, there were anticipations about the walls. The students stated that walls were colorful, painted (sugar pink, yellow-blue, light colored, white, yellow-red, blue, orange-white, blue-pink, red colors), patterned, with the pictures of birds-butterflies and flags. The students described the features of windows; the colors of the glasses are round, the color is wide, the windows are fully open, the color is bright, the color is red, the size is long, they are automatic. The students described the features of curtains; curtains are colorful, regular, the same color as tablecloths, pink, there should be Pepe on the curtains, they are brand new 
and automatic and have flowers patterns. In addition, some students stated that they wanted to paint, decorate, and draw flowers or formulas related to classes. Pictures in everywhere, butterfly on the edges of the board, yellow chalkboard, shelves in some places, open window, clean air, balloons in the class, covered with the pictures of stars, moon, cloud and sun were the features of the classroom mentioned by some students.

Table 7. Expectations about aesthetic design of the class

\begin{tabular}{|c|c|c|}
\hline Expectations & f & $\mathbf{\%}$ \\
\hline Having enough boards & 13 & 25 \\
\hline $\begin{array}{c}\text { Ataturk, the flag and the anthem of } \\
\text { independence }\end{array}$ & 11 & 21 \\
\hline The qualities of the board & 10 & 20 \\
\hline The function of the board & 9 & 18 \\
\hline Other & 8 & 16 \\
\hline Total & 51 & 100 \\
\hline
\end{tabular}

The majority of students stated that boards must be bigger and more, and that the teachers and students should have different special boards. Also, they found that boards were not enough. They expressed that they wanted colored (pink, blue, white...), new, more beautiful, durable and flying board related to the features of the board. With regard to the function of the board, the students expected that the boards tell important people, that there is date-section that it is informative and full of events, and that it has angled corners for texts and pictures. Some of the students stated that the Ataturk and his family section need to be located on the board and that the sections with values such as Atatürk, national anthem and Turkish flag need to be bigger. In addition, they emphasized that boards needs to be solid. Besides, they wanted a corner called the corner of friendship which is filled with the heart and flowers.

The majority of students concentrated on two areas in terms of areas that need to be included in the class. These areas were the library and playgrounds. In relation to the library, students stated that they wanted big libraries which have a wide variety of books and have cushions. Regarding playgrounds, they expressed that they wanted to have toys and other gaming materials (soccer balls, basketball balls, costumes, smart games, etc.).

\subsection{Findings about the Emotional Expectations of the Students}

The majority of students expected a peaceful environment in their classroom regarding of the social relations in the class. They expressed their expectations as follows: "My friends should be good, nice, moral, like family-like my brothers and sisters, well-hearted, helpful, tolerant, cooperative, respectful, friendly, peaceful, optimist and polite". One of the expectations frequently stated was that students did not want to fight in the classroom. In this respect, the students generally said; "Friends are not belligerent, do not push me and each other, do not attack". Students also expected their friends to respect their teachers and to listen to him. In addition, they emphasized that they wanted to be friends with honest and friendly students. Apart from, being in a happy classroom, spending time with friends, reading a book, drawing a picture, being clean and nice and a social life where everyone is fair to each other were the expectations stated less frequently.

Table 8. Expectations on Social Relations

\begin{tabular}{|c|c|c|}
\hline Expectations & f & \% \\
\hline A peaceful environment with my friends & 33 & 42 \\
\hline No fighting & 13 & 17 \\
\hline Respect for the teacher & 6 & 8 \\
\hline Being a best friend & 3 & 4 \\
\hline Being honest & 3 & 4 \\
\hline Making new friends & 3 & 4 \\
\hline Other & 17 & 21 \\
\hline Total & 78 & 100 \\
\hline
\end{tabular}

When the students' expectations about the teacher were examined, the most concentrated expectation was that the teacher is friendly, not angry and not punitive. For this reason, there were even students who expect the teacher to be a woman. Other than that, there were students who said that they want to make his teacher happy by reading poetry, singing songs, and that they do not want his teachers to get tired. Students who wanted different teachers to be in the class for different branches such as the Koran and sports were also observed. It was found that there were students who wanted a less teacher to do less homework, also who wanted a new teacher. Some students expressed that their teachers were always with them and that they did not want to change.

When the expectations of students about academic issues were examined, performing a lot of activity in the class and the necessity of playing educational games were the statements frequently encountered. They were also expected to be hardworking and to be students who score above 90 points on exams. In addition, a classroom environment where they can focus on their lessons for academic success, hanging educational stuff on the walls, the teacher repeating the subject which the students did not understand, expecting the teacher to teach the lesson well, and regular processing of the lessons were mentioned. Also, there were some students expecting that the lessons need to be easy, that the games should be played in the lessons, or the games should be played between the lessons when several lessons are processed, and that the competitions such as multiplication tournaments should be arranged. Apart from, it was observed that students who experienced test anxiety wanted to get rid of this stress. 
Table 9. Expectations for Hygiene

\begin{tabular}{|c|c|c|}
\hline Expectations & f & \% \\
\hline It should be clean & 37 & 67 \\
\hline It should be a recycle bin & 8 & 15 \\
\hline There should be a nice cleaner & 6 & 11 \\
\hline Other & 4 & 7 \\
\hline Total & 55 & 100 \\
\hline
\end{tabular}

A great majority of students on hygiene stated that the classes should be clean, that no garbage should be left in places, and that walls-boards-drapes should not be polluted. Other frequently expressed issues were the availability of a recycle bin in the classroom and the requirement for a good cleaning worker. One student stated that he wanted the trash bin to be like a basketball, and to have fun while throwing the trash. Another subcategory of the security category was that many students wanted cameras in their classrooms. Students wanted the classes to be locked, did not want others to enter their classes, and expected the duty student to be careful in this regard. They also wanted safe windows and the places to be non-slippery. In the emergency subcategory, fire cabin, emergency case and doctor were expected by the students. In the discipline sub-category, the vast majority of students expressed their desire to be quiet during the class hour. The other expectations were stated as having a notebook to write punishments, having a table of rules, not running in the corridor, being careful in the use of the goods, being the assistant of the class.

When the expectations of the students were examined, it was observed that they had expectations in terms of comfort. These expectations were expressed as air conditioning, a luxurious class, a class with full of materials and a comfortable class.

\section{Discussion and Conclusions}

When the results of the study were evaluated, it was observed that the students had much more intense expectations on some subjects. For example, many students expressed the idea that they wanted to sit in a single- seated desk. They also stated that they wanted their desks to be new and beautiful, they even made requests for their colors. In informal interviews with teachers and students, it was observed that the children of primary school did not like to share their desks with their friends in line with their developmental levels, and that the student's friends could adversely affect the desk mate and that they could face the situation of sitting together with the classmates who they did not like due to the changes. Students in these ages can have very different personal preferences. Therefore, it is thought that the support of the students to these differences is important and useful in terms of the development of the students. Similarly, students stated that they wanted beautiful, clean and colorful tablecloths. Students wanted to have a right to talk about their own preferences about the goods they use.

When the compositions of the students were examined, it was observed that they expected a personal Wardrobe to put their bags and special items. Similarly, they expressed that they would like to use either personal lockers or hangers that would be found in the classroom to hang their jackets. They also stated that they wanted to lock their lockers whenever they wanted in order to keep their items safe. The fact that there is a hanger and closet for each student in schools is considered important because it will meet the needs of the students and will save them from the trouble of taking their books and books home.

They expressed that they wanted to use smart boards more effectively in relation to teaching materials in the classroom. Some students expressed their desire to have a SMART Board instead of a normal board, and some students expressed their desire to continue to use the normal board. It is thought that it is important for both students and developing technology to expand the holistic solutions that bring together both the classical school board and the smart board features. This seems to be similar to the results of the research conducted by Ozel [16].

Some of the students expressed their technology-focused expectations with the kind of answers that were unique and could be evaluated in the science fiction category. For example, a self-cleaning toilet, a robot cleaning the class, a security robot, and a robot helping students during the lessons were stated. At this point, it is thought that the ideas of the students should not be ignored and constantly should be consulted because it can create a novelty in the development of technology related to the classrooms. The views evaluated in the science fiction category, although it seems impossible to apply today, are also important in terms of understanding the expectations of the students. Nearly all of the students stated that they wanted their classes to be colorful, decorated and illustrated. The students wanted colorful tables, walls, curtains, boards, floors and doors. They also wanted a clean and tidy class. In these responses, the monotonous and cold structures of the schools continuing from the past to the present were seen to have negative effects on the students. Based on developmental characteristics of the students, it is very important for the schools to have a colorful structure which can be spent great time. Karasolak \& Sari [3] and Ismailoglu \& Zorlu, [4] also found the findings supporting the situation.

On the other hand, two environments in which students intensively wanted to be in their classes were identified. One of them was a library and the other was a playground. Although there were many libraries in the classrooms, it was thought that the classroom libraries should be recovered from the back of the locked cabinets and re-evaluated as a reading area. Also, it was important to support students with resources that may be useful for 
their studies. Apart from that, it was seen that there was a need for indoor playgrounds, especially for climatic reasons, where the students could use between courses. Ekiz and Gulay [17] also seem to pay attention to similar findings in their research.

Students wanted a lot of larger boards. The students in this age group want to see and evaluate the products they produce as part of the process assessment that emerges with constructivist education understanding. Due to the lack of space in the classrooms in general, exhibiting the certain parts of the students' products poses a negative situation for the other students. Therefore, it is important to develop boards in such a way that all of the students can exhibit their products.

At the point of social relations, students stated that they wanted to be peaceful in class environment and did not want to have a fight. Schools are heterogeneous structures in which many socioeconomic and individual backgrounds coexist. It is thought that school administrations should work in this direction in order to transform these structures into a healthy social environment. Regarding the teacher, it was observed that they were expecting a smiling teacher who treated them well, who did not punish them. It is important that teachers who have a very important place in the life of the students and who have become role models for their students continue their education activities in accordance with the requirements of the students and social system in general. At this point, these studies should be supported in teacher training processes that are currently available in the faculties of Education. It was observed that most of the students were interested in being successful and that they wanted to get high scores in the exams. In this context, it is emerged that there is a need for psychological counseling and guidance services of schools to make more intensively studies with students in educational guidance issues.

\section{REFERENCES}

[1] Küçükahmet, L. (1986), Okul binalarının eğitsel kullanımı, Çağdaş Eğitim Dergisi,113: 9-15.

[2] Üstündağ, N. (1999), Akıllı binaların tesisi yönetimi ve iş kalitesi üzerindeki etkileri, Yayınlanmamış doktora tezi, İstanbul Üniversitesi, Fen Bilimleri Enstitüsü, İstanbul.
[3] Karasolak, K., Sarı, M. (2011). Mimari özellikleri farklı okullardaki öğrenci ve öğretmenlerin okullarının binası hakkındaki görüşlerinin incelenmesi. Çukurova Üniversitesi Eğitim Fakültesi Dergisi Cilt:03 No:40 Syf:132-154

[4] İsmailoğlu, S., Zorlu, T. (2018). Yapılandırmacı eğitim felsefesinde dersliklerin mekânsal özellikleri üzerine bir değerlendirme: Rize ili örneği. Online Journal of Art and Design volume 6, issue 1, January 2018148

[5] Loughlin, C. E., Suina, J. H. (1982). The learning enviroment: An instructional strategy, Teachers College Pres, New York.

[6] Aydın, A., (1988) Sınıf Yönetimi, Anı Yayıncılık, Ankara.

[7] Gök, H. ve Gürol, M. (2002). Zaman ve ergonomik açıdan ilköğretim okul binalarının kullanım durumu (Elazığ ili örneği), Fırat Üni. Sosyal Bilimler Dergisi, 12 (2), 263-273.

[8] Uludağ, Z. ve Odac1, H., (2002). Eğitim Öğretim Faaliyetlerinde Fiziksel Mekân, Milli Eğitim Dergisi, Say1153-154.

[9] Küçükoğlu, A., Özerbaş, M. A., (2004). Eğitim Ergonomisi ve Sınıf İçi Fiziksel Değişkenlerin Organizasyonu, Atatürk Üniversitesi Sosyal Bilimler Enstitüsü Dergisi, 4(2).

[10] Zorlu, T., Erbay, M., (2011). İlköğretim Dersliklerinde Ergonomik Açıdan Bir Değerlendirme: Trabzon Örneği, 17. Ulusal Ergonomi Kongresi, 14-16 Ekim 2011, Eskişehir, 234-250.

[11] Alkan, C. (1994). Eğitim ortamlarının düzenlenmesi. Ankara Üniversitesi Basımevi

[12] Akgül, M. K., Yıldırım, F. (1995), Eğitim araçlarının kullanımında ergonomik ölçülerin önemi.5. Ergonomi Kongresi, İstanbul: Milli Prodüktivite Merkezi Yayınları Serisi, No: 372:428-437

[13] Başar, H. (2001), Sınıf yönetimi (5. Baskı), Ankara: Pegem A Yayıncilik.

[14] Terzioğlu, E. (2005), İlköğretim okulu binalarının fiziksel özellikler bakımından değerlendirilmesi, Yayınlanmamıș doktora tezi, Hacettepe Üniversitesi, Sosyal Bilimler Enstitüsü, Ankara.

[15] Yıldırım, A. ve Şimșek, H. (2011). Sosyal bilimlerde nitel araştırma yöntemleri (8. Baskı). Ankara: Seçkin Yayıncılık.

[16] Özel, E. (2014). İlköğretim Düzeyindeki Tarih Eğitiminde Teknolojik Araçların Kullanılma Durumu. Adıyaman Üniversitesi Sosyal Bilimler Enstitüsü Dergisi, 18, 713-740

[17] Ekiz, D., ve Gülay, A. (2018). İlkokul öğrencilerinin “ideal sınıf ortamına" ilișkin metaforlarının belirlenmesi. Kastamonu Education Journal, 26 (4), 1121-1134. doi:10.24106/kefdergi.434147. 